8. Volkova I. (2013) Four Pillars Of Gamification. Middle-East Journal of Scientific - Research 13 - Socio-Economic Sciences and Humanities. P. 149-152.

9. What is gamification? URL: https://www.bunchball.com/gamification

DOI https://doi.org/10.30525/978-9934-26-042-1-43

\title{
ТРАНСФОРМАЦІЯ ТРАДИЦІЙНОЇ ЖУРНАЛІСТИКИ: ВИКЛИКИ СЬОГОДЕННЯ
}

\author{
Ятчук О. М. \\ кандидат наук з соиіальних комунікаиій, доцент, \\ дочент кафедри журналістики \\ Кодацька Н. О. \\ кандидат соиіальних наук, \\ дочент кафедри журналістики \\ Лесюк О. В. \\ кандидат наук з соиіальних комунікацій, \\ старший викладач кафедри журналістики \\ Університету митної справи та фінансів \\ м. Дніпро, Україна
}

Журналістика, як інституціальна структура суспільства, завжди знаходиться у тісному зв'язку не тільки з суспільством, але і з усіма викликами сучасності. Для того, щоб визначити світові тренди, та виклики для професійної діяльності актуальними залишаються численні дослідження та аналітика як аудиторії медіа з їі вподобаннями та особливостями споживання контенту та довіри до діяльності журналістів, як інституції у суспільстві, так і питання загальних тенденцій розвитку в політичному, економічному та соціальному аспектах. Загальні теоретичні методи формалізації, абстрагування, дедукції та інтерпретації дозволяють зробити імовірний прогноз подальшого розвитку професійної діяльності журналістів. Слід зауважити, що в українському просторі через низку об'єктивних та суб'єктивних чинників дослідження щодо трендів розвитку журналістики носять не регулярний характер, окремі дослідження зосереджені або на візькоспецифічних напрямах (наприклад 
дослідження щодо моніторингу маніпуляцій в он-лайні [1] від Інституту масової інформації, або дослідження щодо уподобання та інтересів українців до засобів масової інформації проведено на замовлення ГО «Детектор медіа»[3]), хоча в західних подібні дослідження носять не тільки вузькоспеціалізовані напрями, проте i існують повні звіти, що розкривають тенденції розвитку. Саме тому на наш погляд заслуговують уваги більш загальні дослідження, що допомогли б окреслити та сформувати більш загальне уявлення про функціонування світових та національних трендів в української журналістиці.

Перспективи розвитку сучасної журналістики слід розглядати в контексті змін інформаційного суспільства як такого. Для виокремлення чинників впливу слід розглядати:

- зовнішні чинники впливу (наприклад такі, як пандемія COVID 19), що впливають на динаміку на спосіб споживання інформаційного контенту в певних зовнішніх обставинах;

- трансформацію масового суспільства у бік цифровізації та штучний інтелект ( ШІ), що впливає на технологічний компонент комунікації як такої;

- внутрішні чинники, що демонструють унікальні журналістські рішення в контексті донесення інформаційних повідомлень до аудиторії.

Аналізуючи звіт щодо впливу пандемії COVID 19 в контексті споживання медіа [4-5], ми бачимо, що соціальний, економічний та політичний вплив зовнішніх чинників, що продовжують впливати на суспільство, має тенденцію до концентрації взаємодії з оточуючими, а різноманітні локдауни сприяють трансформації соціальних комунікацій як таких. Зростання технологій для підтримки соціальних контактів [2], віддаленої роботи свідчить, про збільшення технологічного компоненту для формування соціальних зв'язків. Цифровізація сервісів та додатків, через зростання тиску зовнішніх чинників відображається i на журналістській діяльності. Крім того, одним 3 викликів стає використання штучного інтелекту, як для роботи з великим обсягом інформації, так і для створення інформаційних повідомлень за певними алгоритмами. Так, в 2020 році вперше журналісти телебачення працювали через веб-камери з дому, у якості гостей для прямоефірних телевізійних програм залучають фахівців з виростанням мобільного зв'язку та відеоконференцій, $\mathrm{i}$ це стає вже трендом сучасного телебачення. Крім загальних чинників, що є характерними для світових тенденцій, $\epsilon$ i унікальні риси, притаманні саме українській журналістиці, наприклад роздержавлення медіа. як стала тенденція, або 
розвиток громадської журналістики на тлі політичних та демократичних трансформацій українського суспільства.

Крім того, слід додати і таки чинники, безпосереднього впливу на журналістський контент як:

- зростання пристроїв для мобільної взаємодії (перегляд аудіовізуального контенту, взаємодія 3 соціальними мережами, споживання інформаційного контенту);

- психологічні особливості аудиторії, що базуються на довірі (тенденції медіа критики та фактчекінгу);

- взаємодія з традиційними та новітніми медіа, та як наслідок вплив на трансформацію традиційної журналістики як такої.

Дослідження аудиторії доводять, що на сучасному етапі ми можемо виокремити таки трансформаційні тренди як:

- традиційні медіа, хоча і втрачають аудиторію, через активний розвиток інтернет комунікацій, проте продовжують зберігати довіри аудиторії щодо телепереглядів;

- питання локальних медіа стоїть доволі гостро, економічні чинники зменшують їх кількість, особливо гостро ці питання стосуються пресової журналістики ( обмежують друковані версії видань), і окремих напрямів ( наприклад спортивної журналістики);

- розмивається поняття новини, як такої, медіа перестають бути унікальним джерелом новинного контенту, поступаючи позиції індивідуальному впливу через соціальні мережі та окремих інфлюенсерів;

- залучання аудиторії як до оплати журналістських послуг (унікальних матеріалів для тих, хто оплатив доступ), так і на підтримку видання за кошт аудиторії (різноманітні пожертвування);

- подкастінг, як напрям журналістики та поширення аудіо-формату, як такого;

- використання ШІ для обслуговування інформаційних потреб аудиторії, як технологію формування інформаційного порядку денного так і певної адаптації і трансформації повідомлень;

- використання власних даних користувачів і взаємодія з великими технологічними компаніями, як постачальниками контенту;

- роль платформ та соціальних мереж стає все більш політизованою в контексті виборів та викликів демократичного суспільства у світі;

- боротьба $з$ дезінформацією та фейками пов'язане із зростанням невизначеності в аудиторії, що певною мірою відображається і на довірі до традиційних медіа.

Проте, ми бачимо, що серед досліджень переважна більшість зосереджена саме на дослідженнях уподобань, проте різноманітні фокус групи з стейкголдерами, експертні опитування представлені 178 
дуже обмежено, що не дозволяє досліджувати тренди всебічно, враховуючи і саморефлексію самих представників медійної галузі та журналістики зокрема.

Таким чином, ми бачимо, що лонгітюдні дослідженні, спрямовані як на вивчення аудиторії, так і на експертні оцінки представників журналістських професій, дозволять всебічно розглядати процеси, які впливають та знаходять своє відображення в медіа. Спостереження за західними студіями та порівняння сучасного досвіду в контексті конгломерації дозволять виокремлювати не тільки спільні тенденції розвитку, а і усвідомлювати унікальність, як імовірну тенденцію, у подальшому дослідженні тих, чи інших чинників. Крім того, одним 3 перспективних напрямів $є$ удосконалення методології досліджень, що враховувала б не тільки традиційні інструменти та методи, але і додавала сучасних технологій, особливо в контексті використання штучного інтелекту.

\section{Література:}

1. Найбільше новин з маніпуляціями публікують онлайн-медіа в Дніпрі й Полтаві. Інститут масової інформації. 02.02.2021. https://imi.org.ua/monitorings/najbilshe-novyn-iz-manipulyatsiyamypublikuyut-onlajn-media-dnipra-i-poltavy-i37497 (дата звернення 10.02.2021)

2. Попит на сервіси для відеоконференцій зріс більше ніж у 7 разів - досілдження. Економічна правда. 14 квітня 2020. https://www.epravda.com.ua/news/2020/04/14/659344/ (дата звернення 10.02.2021)

3. Як змінились уподобання та інтереси українців до засобів масової інформації після виборів 2019 р. та початку пандемії COVID-19. Детектор Медіа. 29.09.2020 https://detector.media/infospace/article/ 181066/2020-09-29-yak-zminylys-upodobannya-ta-interesy-ukraintsiv-dozasobiv-masovoi-informatsii-pislya-vyboriv-2019-r-ta-pochatku-pandemiicovid-19/ (дата звернення 10.02.2021)

4. Nic Newman,Richard Fletcher,Lucy Kueng Rasmus Kleis Nielsen, Meera Selva, and Eduardo Suárez. Journalism, Media, and Technology Trends and Predictions $2020 \mathrm{https} / / /$ reutersinstitute.politics.ox.ac.uk/sites/default/ files/2020-01/Newman_Journalism_and_Media_Predictions_ 2020_Final.pdf (дата звернення 10.02.2021)

5. Nic Newman, Richard Fletcher, Anne Schulz, Simge And1, and Rasmus Kleis Nielsen. Reuters Institute Digital News Report 2020. https://www.digitalnewsreport.org/ (дата звернення 10.02.2021) 